\title{
EFL MATERIALS IN TEACHING LISTENING: PERSPECTIVES FROM INDONESIA AND VIETNAM
}

\author{
Nguyen Thi Hong Nhat ${ }^{1 *}$; Francisca Maria Ivone ${ }^{2}$ \\ 1. Faculty of Foreign Languages, Hanoi Pedagogical University 2 \\ Nguyen Van Linh Street, Xuan Hoa, Phuc Yen, Vinh Phuc \\ 2. Department of English, Universitas Negeri Malang, Indonesia
}

Received 27 February 2020

Revised 31 July 2020; Accepted 29 November 2020

\begin{abstract}
The practices of selecting and using materials for the teaching of listening skill have not yet been examined widely in the literature of materials development in language teaching (Hill \& Tomlinson, 2013). This paper presents a cross-analysis of type, selection procedures, and design of English as a Foreign Language (EFL) materials for teaching listening at two public universities, one in Vietnam and the other one in Indonesia. This paper is built upon 15 years of personal experience of two lecturers who have worked in the education system of Vietnam and Indonesia. The analysed data included the course profiles, syllabi, and listening materials used in the two EFL undergraduate language education programs. By providing revealing comparisons of the selection and usage of EFL listening materials in two language programs in Indonesia and Vietnam, this paper hopes to contribute to the literature of materials development and selection for language teaching in Asia as well as around the world.
\end{abstract}

Keywords: listening skill, listening materials, listening textbook, materials development, materials selection, Vietnam, Indonesia.

\section{Introduction}

The practices of selecting and using materials for the teaching of listening skill have not yet been widely examined in the literature of materials development in language teaching(Hill \& Tomlinson, 2003, 2013). This paper presents a cross-analysis of types, selection procedures, and designs of English as a Foreign Language (EFL) materials for teaching listening at two public universities, one in Vietnam and the other one in Indonesia. The analysed data included the course profiles, syllabi, and listening materials used in the two EFL undergraduate language education programs. The paper begins with an overview of the cases of Vietnam and Indonesia regarding EFL materials in teaching listening. It then presents a cross-analysis of the two cases.

* Tel.: 0987891339

Email: nguyenthihongnhat@hpu2.edu.vn
The paper concludes with some implications of the study on textbook selection and the role of teachers as designers of materials.

\section{ELT curriculum design}

The literature has highlighted primary stages in ELT curriculum design (Johnson, 1994; Nunan, 1988). Nunan(1988) commented that a language course should go through the process of planning, implementation and evaluation. Johnson (1994) further elaborates Nunan's (1988) framework and adds that to achieve a coherent curriculum, the four key stages of development are: curriculum planning, ends/means specification, programme implementation, and classroom implementation. In each stage, different stakeholders play important roles in making the 'content' and 'methodology' consistent and useful. 
Table 1. Stages, decision making roles, products in curriculum development

\begin{tabular}{lcc}
\hline \multicolumn{1}{c}{ Developmental stage } & Decision making roles & Products \\
\hline 1. Curriculum planning & policy makers & policy document \\
2. Specification: ends & needs analysts & syllabus \\
means & methodologists & \\
3. Programme implementation & materials writers & teaching materials \\
& teacher trainers & teacher training \\
4. Classroom implementation & teachers & teaching acts \\
& learners & learning acts \\
\hline
\end{tabular}

Johnson's framework emphasizes collaboration at each stage among different stakeholders and the continuous evaluation of programs.

\section{Textbook selection approaches}

The literature has highlighted two primary approaches for textbook selection. The first approach is top-down in which textbooks are often selected by administrators or senior lecturers (Tomlinson, 2008). This approach has been used in many countries such as Korea, Kenya, and Japan. The second approach is bottom-up approach in which teachers and learners have voice and are involved in the process of textbook selection. In this approach, teachers of the same course together consider the general goals of the program and have responsibility to work together to discuss the criteria to select relevant textbooks to their programs. This approach is common in several countries such as Britain, Hong Kong and France.

While these two approaches have been employed in different countries, the top-down approach is more popular than the bottomup approach. In a survey of twelve countries worldwide, Tomlinson (2008) found that nearly " 85 percent of ELT textbooks were selected by administrators, 15 per cent by teachers and 0 per cent by learners". This reflects the fact that not many teachers and learners play important roles in the process of selecting textbooks in their countries. The next section critically reviews the type, selection procedures, and design of EFL materials for teaching listening in two cases, one in Vietnam and the other one in Indonesia.

\section{The Vietnam Case}

\subsection{The role of textbook in EFL courses}

The use of textbooks for EFL teaching and learning is compulsory at all educational levels in Vietnam, including the higher education level (The Ministry of Education and Training [MOET], 2011). MOET provides detailed guidelines on the design, selection, evaluation, approval and use of course textbooks in higher education in Circular No. 04/2011/ TT-BGDĐT (MOET, 2011). Accordingly, universities have to ensure that each language course uses at least one textbook for learning and teaching purposes. Universities may opt to design their own textbooks or to select commercial textbooks on the market as long as they are relevant and compatible with the goals and objectives of the program and the language proficiency framework issued by MOET. This leads to the fact that different universities may choose/design different textbooks for the same course name and level (Nguyen, 2019). For instance, a Listening 1 course for first year, first semester English Department students in one university may use a commercial textbook of pre-intermediate level. Another university may offer the same 
course name at intermediate level and use a module developed by the lecturers teaching the course.

As the main source of materials used in the course, textbooks are suggested to be used as guidance of teaching and learning activities. Teachers should follow the topics and units stated in textbooks. However, teachers are allowed to make modifications to the contents of textbooks to fit students' needs and the learning context.

\subsection{Textbook selection procedures}

The process of selecting and designing textbooks and syllabi is presented in Figure 1. It is implemented using a top-down approach and decided at the university level.

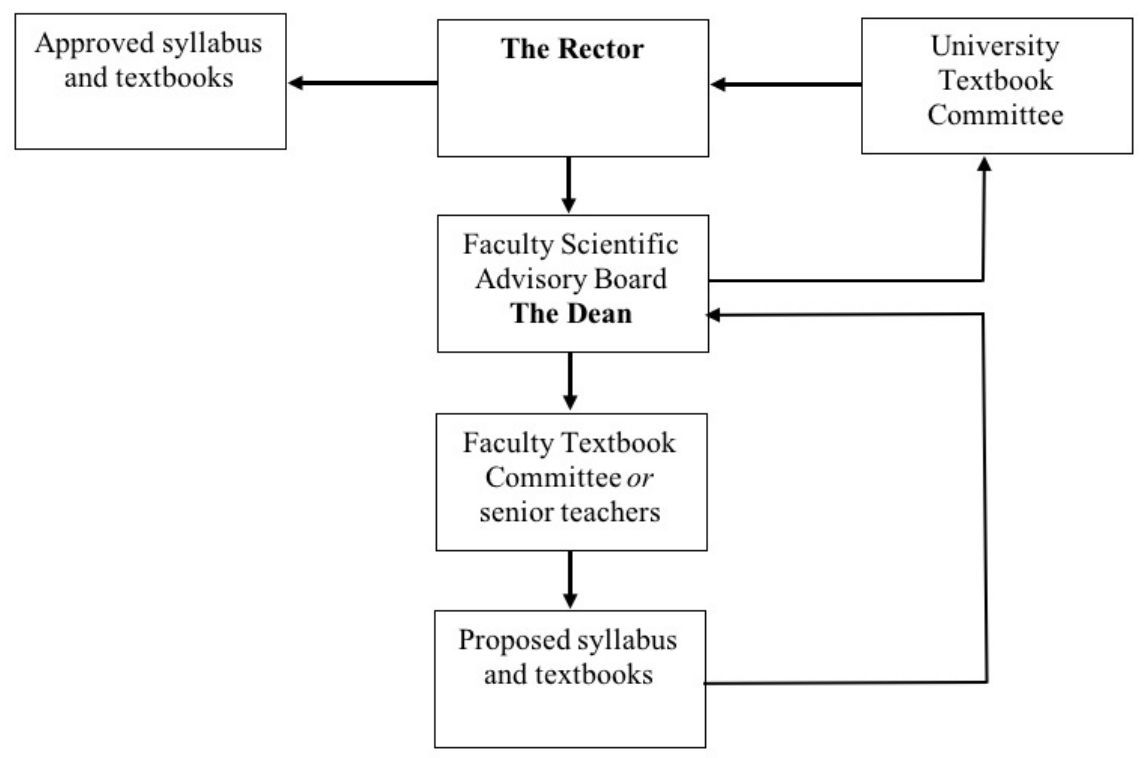

Figure 1. The process of textbook design/selection at the institutional level

To select or design textbook(s) for a course in a program, the rector assigns the Faculty Scientific Advisory Board, which is led by the dean, to conduct this task. Then the dean can establish a Faculty Textbook Committee or directly appoint one or more lecturers to develop the syllabus and select the textbook(s) for each course. The dean needs to ensure that the selected teachers have relevant qualifications and considerable experience in teaching the course. The syllabus for the course must clearly state the structure of the course, course textbooks and supplementary materials. It should be noted that in Vietnam, the syllabus is usually developed based on the textbook content (Le, 2011; Phan, 2015). The proposed syllabus and the textbook(s) are then submitted to the Faculty Scientific Advisory Board that sends them to the University Textbook Committee to be reviewed. The rector then considers the results of the review process and approves the syllabus and textbooks for official adoption. Only after they are being approved by the rector, the selected textbooks and syllabi are put into use locally in their institutions. Thus, in many cases, lecturers just follow the approved syllabi and textbooks and do not choose the textbooks for their own courses. The approved textbooks and syllabi can be 
used for many years until the faculty advises the rector about a new selection of textbooks. However, due to a lack of resources it usually takes universities years to select and purchase new textbooks.

\subsection{The design of teaching and materials for teaching listening}

As mentioned in the previous section, textbooks can be combined or selected from the market for official use in the university by the textbook committee. However, it is common that universities will select rather than combine textbooks. For example, four listening courses in the language program used four commercial textbooks, i.e., Get ready for IELTS: Listening A2+; Listening for IELTS; Real listening B2-C1; Real lives, Real listening B2-C1. Contents of these textbooks are theme-based and cover various topics that students might experience in their real-life listening. For instance, the topics included in Get ready for IELTS: Listening A2+ are Friend Abroad, Food and cooking, Work, and On campus service.

In teaching, teachers often structure their lessons into three phases, i.e., pre-listening, while-listening and post-listening. While in the while-listening phase, teachers follow the tasks designed in the textbooks, they have more freedom to modify the pre-listening and post-listening tasks. These two phases allow teachers' creativity to make lessons better fit their students' level and interest.

While MOET regulates that textbook usage is compulsory, it is making genuine efforts to give teachers more autonomy. MOET has issued a number of policy documents to encourage teachers to design and use a variety of learning materials to supplement textbooks (MOET, 2008; VietCALL, 2014). Accordingly, teachers can exploit
Web 2.0 computer technologies to expand learning materials and to provide students with authentic and meaningful learning experiences. It is shown in the course profile that in addition to the textbook, lecturers are encouraged to use various online materials including websites, YouTube videos, and podcasts. It can be seen that in Vietnam the textbook is the primary learning material and teachers have some freedom to use or design additional online materials to supplement it.

\section{The Indonesia Case}

\subsection{The role of textbook in EFL courses}

The use of textbook in EFL classes at the university level in Indonesia is not strictly regulated by the government nor the university. Each lecturer is given the autonomy to select appropriate resources for his/her class based on the standards set by the Ministry of Research and Higher Education [MRHE] of the Republic of Indonesia, the university, and the study program. MRHE sets the minimum standards of higher education in the MRHE Regulation of the Republic of Indonesia No. 44 Year 2015 on the national standard of higher education. The standards include graduate attribute, course content, teaching and learning process, assessment, academic and non-academic staff, facilities, learning management, and learning expenses standards. In regards to course content lecturers are given the freedom to use any resources to meet the graduate attributes set by the university and the study program. The education guidelines published by the university require that before the semester commences, lecturers have to have prepared learning resources used in their courses that may take the form of recommended and suggested books and additional information. The study program sets the program learning 
outcomes and design course descriptions (English Department Catalogue, 2017). Lecturers or groups of lecturers teaching the same course determine the course learning outcomes and prepare resources needed in these courses.

There are four listening courses offered in the $1^{\text {st }}$ to $4^{\text {th }}$ semester at the Department of English, Universitas Negeri Malang: Intensive Course Listening, Basic Listening, Intermediate Listening and Advanced Listening. Each course is taught by four to five lecturers and uses modules developed by some of the lecturers teaching these courses. The modules are used as the main coursebook. All lecturers are given the authority to use supplementary materials to suit the needs and interests of their classes.
The modules are compiled from many resources and include multimedia materials. They are revised every four to five years.

\subsection{Textbook selection procedures}

Before each semester commences, all lecturers, individually and in groups, develop a Course Profile (CP) for each of the classes they teach that semester. CPs should be made available for students at the beginning of every semester. They are developed to help students understand the teaching and learning methods that enable the outcome to be achieved; the assessment methods that enable achievement to be demonstrated; and the relationship of the program and its study elements. Specific learning resources are detailed in the CPs. This includes the module and supplementary materials.

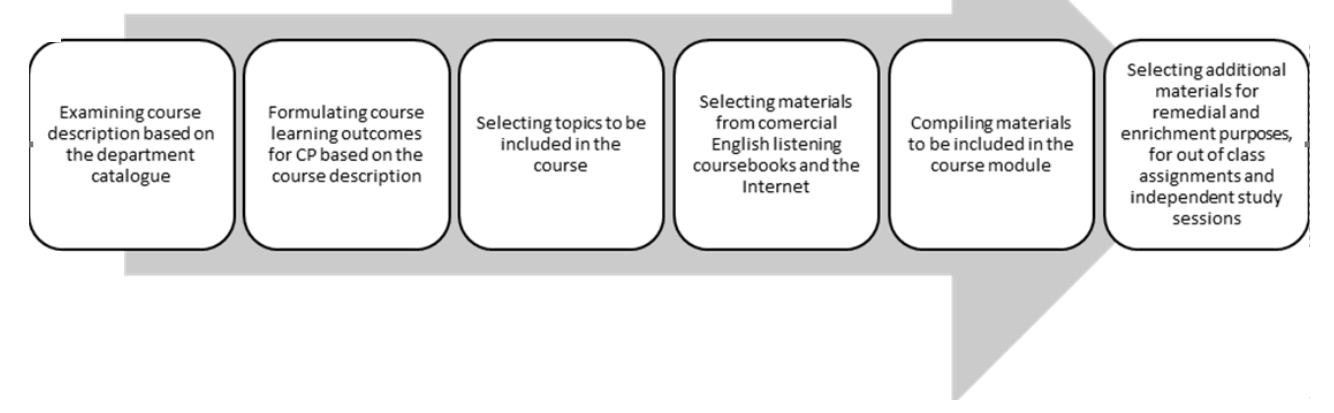

Figure 2. The process of material design/selection at the study program level

The process of learning resources selection starts with the formulation of course learning outcomes which are derived from the course description. Once the course learning outcomes are identified, the course syllabus is created. Based on the syllabus, learning resources are selected from various listening textbooks and compiled into a module. The module is the main coursebook, each lecturer then selects his/her own supplementary materials and lists them in the CP. The materials are used in class as well as outside class as part of out of class assignments and independent study materials. More additional resources can be added as the semester progresses to address the needs and interest of the students. Some classes may need enrichment materials while other classes need remedial materials.

\subsection{The design of teaching and materials for teaching listening}

The materials for teaching listening are commonly selected based on topics. Table 2 lists the topics for the four listening courses 
currently offered by the study program. Intensive Course Listening course is a four credit course that meets twice a week. Thus it covers more topics than the other three listening courses that only meet once a week. It can be seen that the topics in Intensive
Course Listening and Basic Listening courses are very familiar and related to language functions and basic grammatical structures. The Intermediate and Advanced Listening courses cover more general topics.

Table 2. The list of listening course topics

\begin{tabular}{|c|c|c|c|}
\hline $\begin{array}{c}\text { Intensive Course } \\
\text { Listening } \\
\end{array}$ & $\begin{array}{c}\text { Basic } \\
\text { Listening } \\
\end{array}$ & $\begin{array}{c}\text { Intermediate } \\
\text { Listening } \\
\end{array}$ & $\begin{array}{c}\text { Advanced } \\
\text { Listening } \\
\end{array}$ \\
\hline Nice to meet you. & He's the generous type. & Language learning & Family life \\
\hline How do you spell that? & We could get him a tie. & Work & Noise \\
\hline What language do you & What exactly do you & Travel & Far from home \\
\hline speak? & do? & Adventure & Sex discrimination \\
\hline What time is it? & Going into business. & Personality & GWR FM \\
\hline What time do you get up? & Clothes and going out. & Living situations & Save our earth \\
\hline Where is it? & It doesn’t fit. & Habits & Loud and aggressive \\
\hline What does it look like? & I'm not sure what it's & Culture & Sarajevo \\
\hline What do you do? & called. & Money & Jigsaw of a village \\
\hline What do you do in your & A global language. & Disaster & All you need is love? \\
\hline free time? & I thought you spoke & Technology & The great ruby \\
\hline Can you call me back? & English. & Advice & robbery \\
\hline What does she look like? & You'll buy anything. & Current affairs & HERE (the poem) \\
\hline What are they doing? & Advertising works. & & \\
\hline Do you have? & Our sales target is $\$ 1.1$ & & \\
\hline Where should we put the & million. & & \\
\hline lamp? & Communication. & & \\
\hline Do you like living here? & I have a driving lesson & & \\
\hline Is the post office that way? & tonight. & & \\
\hline How much is the t-shirt? & & & \\
\hline What happened then? & & & \\
\hline \multicolumn{4}{|l|}{ Did you have a good time? } \\
\hline Is it cloudy or sunny? & & & \\
\hline \multicolumn{4}{|l|}{ What are you going to do? } \\
\hline \multicolumn{4}{|l|}{ Where will you go? } \\
\hline \multicolumn{4}{|l|}{ I love hamburger! } \\
\hline \multicolumn{4}{|l|}{ How was your vacation? } \\
\hline \multicolumn{4}{|l|}{$\begin{array}{c}\text { What about a movie } \\
\text { tonight? }\end{array}$} \\
\hline \multicolumn{4}{|l|}{ Would you mind? } \\
\hline \multicolumn{4}{|l|}{ Is bigger better? } \\
\hline \multicolumn{4}{|l|}{ How do we turn it on? } \\
\hline \multicolumn{4}{|l|}{ What should I do? } \\
\hline I couldn't agree more. & & & \\
\hline
\end{tabular}


The classroom activities carried out based the modules can generally be divided into three main stages:

- Pre-listening activities to prepare for listening, which may be in the form of: observing and/or discussing pictures, diagrams or other visuals; reviewing vocabulary or grammatical structures; reading texts relevant to the topic of discussion; constructing semantic webs or other graphic organizers (a graphic arrangement of concepts or words showing how they are related); predicting the content of the listening text; going over the directions or instructions for the activity, etc.

- Whilst-listening activities to help focus attention on the listening text and develop understanding of it, which may be in the form of: listening for the gist; filling in graphs or charts; checking off items in a list; identifying errors; searching for specific clues to meaning; completing cloze exercises; arranging jumbled text; answering factual, inferential and argumentative questions; note-taking; reading the transcript, etc.

- Post-listening activities to help reinforce comprehension of a text, which may be in the form of: making a summary; retelling the content of the text; discussing and responding to the contents of the text; creating similar texts to the text learners listened to, etc.

In addition to these classroom activities, extensive listening activities are also strongly encouraged through class assignments and independent study tasks. Additional materials are generally taken from English learning websites as well as websites which are not for language learning purposes.

\section{The cross-analysis}

A cross-analysis of the cases of Vietnam and Indonesia universities regarding the type, selection procedures, and design of EFL materials for teaching listening results in some similarities and differences. Table 3 presents a summary of the similarities and differences between two cases.

Table 3. Similarities and differences of the type, selection procedures, and design of EFL materials between Indonesia and Vietnam

\begin{tabular}{ccc}
\hline Aspects & Indonesia & Vietnam \\
\hline $\begin{array}{c}\text { Textbook selection } \\
\text { approach } \\
\text { Course syllabus }\end{array}$ & Bottom-up approach & Top-down approach \\
The textbook & $\begin{array}{c}\text { Developed before selecting the } \\
\text { textbook }\end{array}$ & Based on the chosen textbook \\
& - a compilation of materials & - a whole published textbook \\
& - in-house & - commercial textbooks \\
Supplementary materials & - theme-based & - theme-based \\
& - Teachers have freedom to choose \\
& - Teachers opt for online materials \\
\hline
\end{tabular}

The main difference is in the selection procedures of textbooks and the course syllabus. In the Vietnam case, textbook selection has to go as high as the university rector for formal approval. In the Indonesian case, lecturers have the freedom to choose the textbooks they use in teaching listening courses. In the Vietnam case, course syllabus 
is developed based on the textbook chosen, while in the Indonesian counterpart it is the other way around. Yet, the condition is actually quite similar. In both cases, a listening course uses one main coursebook and supplementary materials. It is the format of the coursebook which is different. In the Vietnam case, a coursebook is a whole textbook selected for the course, while in the Indonesian case, it is a compilation of materials from various resources. In regards to supplementary materials, in both cases, lecturers are given the opportunity to be more creative in the selection of materials. Online resources are definitely the most widely used supplementary listening materials in both cases. Regarding the design of materials, it can be seen that in Vietnam, teachers often use commercial textbooks rather than in-house ones. However, it is common in Indonesia that teachers combine textbooks from various resources. The similar feature about the design of textbooks in Vietnam and Indonesia is that textbooks are usually theme-based. They cover topics that students are likely to experience in their real-life listening.

The findings showed that while textbooks were the primary materials in the program in Vietnam as it was mandated by the Ministry of Education, in Indonesia this was the prerogative of the lecturers. Moreover, in Vietnam, textbooks were selected following a hierarchical procedure, unlike in Indonesia in which they were chosen collaboratively by those teaching the listening courses. Although both the Vietnamese and Indonesian lecturers in the two language programs were allowed to use and design online materials to supplement the textbooks, the degree of freedom in using this type of material varied. The study suggests that there is a need for lecturers to work collaboratively in selecting and designing textbooks and supplementary materials for their listening courses. Moreover, lecturers should be encouraged and facilitated in equipping themselves with the relevant skills and knowledge to effectively play the role of instructional material designers.

\section{Implications of the study}

\subsection{Listening to language teacher's voice}

A key finding in this study was that in Vietnam, textbooks played a critical role in EFL teaching in Vietnam and the teachers had to use the textbooks chosen by others. Unlike in Indonesia, textbooks were chosen collaboratively by those teaching the listening courses. The results of this study do not support the idea of removing textbooks altogether but suggest an acknowledgement of the teacher's right to be involved in the decision of selecting and using textbooks for their language courses. In the context of Vietnam where the Ministry of Education and Training requires that textbooks in use need to be approved, they should be selected by textbook committees of elected teacher representatives. Instead of following a topdown procedure in which senior teachers are usually entrusted to select/design textbooks, institutional managers could delegate that responsibility to working groups between relatively junior staff and senior colleagues teaching the same course. By this way, as Johnson (1994) and Hoang (2015) suggested, they could work collaboratively to discuss the criteria to select textbooks which are relevant and meaningful to students and fit the assessment formats for which students have to be prepared for. This approach would, as McGrath (2013) pointed out, ensure a greater match between textbooks, examinations and learners because teachers could integrate teaching syllabus, textbook and assessments. In Vietnam, there have been teachers who are 
more autonomous in designing and selecting textbooks. However, there should be favorable policies to encourage and empower teachers to be more active, autonomous and creative in material selection and design.

\subsection{Empowering teachers as designers of CALL materials}

Another implication of this study is that it has extended the understanding of the role of EFL teachers as designers of CALL materials. The study has identified that lecturers in the two language programs in both Vietnam and Indonesia had freedom, though varied, to use and design online materials to supplement the textbooks chosen for listening courses. The findings of the current study suggest that there is a need to explicitly recognise and support teachers to develop their roles as designers of materials. Acknowledging the role of EFL teachers as designers of CALL materials has an important implication. This study has demonstrated that teachers do select materials to fit their particular students' needs. Thus, the argument might be that educational leaders should encourage and support teachers to find materials which fit their students and their time constraints, especially in a context where resources for purchasing commercial materials are limited. In other words, teachers should be empowered with the knowledge and skills to select materials for their own courses and to work collaboratively with other lecturers for preparing for the same courses.

\section{Conclusion}

The paper has provided revealing comparisons of the selection and usage ofEFL listening materials in two language programs in Indonesia and Vietnam. It showcases the differences and similarities in the way EFL listening materials are selected, used or/and designed in two developing countries. The paper suggests two important implications for the issues of materials selection and teachers' roles as designers of instructional materials. Giving lecturers the responsibility to select and design listening materials will in one hand give them the freedom to use varied, authentic, meaningful and up-todate materials but on the other hand require them to be more skillful and knowledgeable. Thus creativity and collaboration should be fostered and a bottom-up approach to material selection and design should be implemented.

\section{Acknowledgement}

This research was funded by Hanoi Pedagogical University 2 Foundation for Science and Technology Development via grant number: C.2019-18-01.

\section{References}

\section{Vietnamese}

Bộ Giáo dục và Đào tạo. (2011). Thông tu số 04/2011/ TT-BGDĐT về viẹc ban hành quy định biên soạn, lựa chọn, thẩm định, duyệt và sủ dụng giáo trình giáo duc đại học [Circular $\mathrm{N}^{0}$ 04/2011/TT-BGDĐT on the design, selection, evaluation, approval and use of course textbooks in higher education]. Hà Nội: Bộ Giáo dục và Đào tạo.

VietCALL. (2014). Báo cáo chiến lược ứng dụng công nghệ thông tin trong dạy và học ngoại ngữ [Action plan for the enhancement of CALL]. Hà Nội: Đề án Ngoại ngữ Quốc gia 2020.

\section{English}

English Department. (2017). English Department Catalogue. Malang, Indonesia: Universitas Negeri Malang.

Hoang, V. V. (2015). The development of the ten-year English Textbook Series for Vietnamese schools under the National Foreign Language 2020 Project: A cross-cultural collaborative experience. VNU Journal of Foreign Studies, 31(3), 1-17. Retrieved from https://js.vnu.edu.vn/FS/article/ view/15

Hill, D. A., \& Tomlinson, B. (2003). Coursebook listening activities. In B. Tomlinson (Ed.), Developing materials for language teaching ( $\mathrm{pp}$. 364-374) (1st ed.). London: Continuum. 
Hill, D. A., \& Tomlinson, B. (2013). Coursebook listening activities. In B. Tomlinson (Ed.), Developing materials for language teaching (pp. 384-521) (2nd ed.). London: Continuum.

Johnson, R. (1994). The Second Language Curriculum. Cambridge: Cambridge University Press.

Le, V. C. (2011). Focus on form instruction: A case study of Vietnamese teachers' beliefs and practices. Doctoral dissertation, The University of Waikato. Retrieved from https://researchcommons.waikato. ac.nz/handle/10289/5253

McGrath, I. (2013). Teaching materials and the roles of EFL/ESL teachers: Practice and theory. London: Bloomsbury.

Ministry of Research and Higher Education. (2015). Regulation 44 on the national standard of higher education. Indonesia: Ministry of Research and Higher Education.
Nguyen, T. H. N. (2019). Evaluating an educational innovation: Professional development in CALL at the tertiary level in Vietnam. Doctoral dissertation, School of Languages and Cultures, The University of Queensland. https://doi.org/10.14264/uq1.2019.127

Nunan, D. (1988). Syllabus Design. Oxford: Oxford University Press.

Nunan, D. (1989). The Learner-centred Curriculum: a Study in Second Language Teaching. Cambridge: Cambridge University Press.

Phan, N. T. (2015). Approaches to curriculum development in Vietnamese higher education: A case study. Doctoral dissertation, Queensland University of Technology. Retrieved from https://eprints.qut. edu.au/84906/

Tomlinson, B. (Ed.). (2008). English language teaching materials: A critical review. London: Continuum.

\title{
TÀILIẸUTIẾNGANHTRONGGIẢNGDẠYỸNĂNGNGHE: GÓC NHİN TỬ INDONESIA VÄ VIẸTT NAM
}

\author{
Nguyễn Thị Hồng Nhật ${ }^{1}$; Francisca Maria Ivone ${ }^{2}$ \\ 1. Khoa Ngoại ngũu, Trưòng Đại học Su phạm Hà Nội 2 \\ Đuờng Nguyễn Văn Linh, Xuân Hòa, Phúc Yên, Vĩnh Phúc, Việt Nam \\ 2. Khoa Ngoại ngũu, Trương Đại học Negeri Malang \\ Malang, Jawa Timur, Indonesia
}

Tóm tắt: Bài viết trình bày kết quả phân tích về loại hình, quy trình tuyển chọn và thiết kế tài liệu tiếng Anh để giảng dạy kỹ năng nghe tại hai trường đại học công lập, một ở Việt Nam và một ở Indonesia. Bài viết được xây dựng dựa trên 15 năm kinh nghiệm cá nhân của hai giảng viên đã làm việc trong hệ thống giáo dục tại hai quốc gia này. Dữ liệu được phân tích bao gồm đề cương học phần, giáo trình và tài liệu bổ trợ được sử dụng trong hai chương trình giáo dục ngôn ngữ đại học. Bài viết này hy vọng sẽ đóng góp thêm vào lý thuyết phát triển và lựa chọn tài liệu việc giảng dạy ngôn ngữ ở châu Á cũng như trên thế giới.

Tù khóa: kỹ năng nghe, tài liệu nghe, sách giáo khoa nghe, phát triển tài liệu, lựa chọn tài liệu, Việt Nam, Indonesia. 